\title{
Multi-level Approaches to Countering Unconstitutional Changes of Government in Africa: Implications for the Rule of Law
}

Journal of Asian and African Studies 2019, Vol. 54(4) 467-484 (C) The Author(s) 2019 Article reuse guidelines: sagepub.com/journals-permissions DOI: $10.1177 / 0021909618824348$ journals.sagepub.com/home/jas

@SAGE

\section{Theresa Reinold}

Institute of Political Science, Duisburg-Essen University, Germany

\begin{abstract}
This article assesses the impact of multi-level approaches to the problem of unconstitutional changes of government (UCGs) on the rule of law at the national and global level. Based on a single-case study of the 2016 Gambian UCG, this article concludes that multi-level governance tends to strengthen the rule of law at the national level, but only if certain conditions are met. These include an agreement about the rules of the road regulating how the different layers of governance interact - subsidiarity v. precedence for organizations from higher levels of governance - and the definition of a common purpose. Such unity of purpose is easier to attain if the (geo)political stakes of a crisis are relatively low, the prospects of success of a military intervention high, and if the perpetrators of the UCG have forfeited their legitimacy both locally and globally. This prevents them from exploiting institutional rivalries and shrinks their space for diplomatic manoeuvre and thus their ability to use forum shopping for their benefit. If these conditions are met, then multi-level responses to UCG will strengthen the rule of law at the domestic level, while at the same time potentially undermining the rule of law at the global level.
\end{abstract}

\section{Keywords}

Unconstitutional change of government, multi-level governance, rule of law, ECOWAS, African Union, The Gambia

\section{Introduction}

Viel hilft viel is a German expression that can roughly be translated as 'more is more'. But when is more really more? Regarding the topic of this article - unconstitutional changes of government (UCGs) in Africa - we must ask whether the multitude of organizations, norms and policies that operate at different levels of governance, and which seek to address the problem of UCGs, actually produce the desired result of strengthening the rule of law. This article thus looks at the problem of UCGs from the perspective of multi-level governance (MLG) and asks if more really is more, or if the multi-level response to UCGs teaches us that we should stick to the conventional wisdom according to which often less is more. 
While there is a burgeoning literature on the African Charter on Democracy, Elections and Governance (ACDEG), and on the specific issue of UCGs (see for example Elvy, 2013; Engel, 2010; Glen, 2012; Leininger, 2014; Obse, 2014; Vandeginste, 2013; Wiebusch, 2016), and while here and there issues of subsidiarity, norm collisions, institutional rivalries, etc. pop up (see for example Lanz and Gasser, 2013; Nathan, 2013, 2016), the topic has rarely been systematically explored from the perspective of MLG. MLG often comes with a significant degree of legal pluralism and overlapping spheres of influence, and thus poses salient questions for the rule of law: here defined broadly as the requirement that a community be governed by legal rules, not by the whims of men (Cass, 2004: 131). I deliberately adopted a rather general definition of the rule of law, as I seek to flesh out how actors from different levels of governance have interpreted the concept of the rule of law in responding to UCGs. A more rigid a priori definition of the rule of law would have precluded an analysis of how the concept is filled with meaning by actors from different sociopolitical and cultural backgrounds. ${ }^{1}$

Now, why focus on Africa? For one, because African approaches to countering UCGs are highly innovative; and secondly, because the practice of one quarter of the world's states cannot be ignored in understanding how global norms of constitutional governance evolve. The African Union (AU) has established a rather comprehensive framework aimed at promoting constitutional rule in member states. African efforts to give substance to the democratic entitlement include, inter alia, Art. 30 of the AU Constitutive Act, which declares that governments coming to power through unconstitutional means shall not be allowed to participate in the activities of the continental organization (African Union, 2000), the adoption of the ACDEG (African Union Assembly, 2007), as well as the 2003 amendment of the AU Constitutive Act (African Union Assembly, 2003). This amendment, which has not entered into force yet, expands the scope of Art. 4(h), authorizing the AU to intervene in member states in the event of a 'serious threat to legitimate order' - militarily if necessary (African Union Assembly, 2003).

In particular, the broadening of Art. 4(h) raises thorny issues for the international legal order. While one could argue that the AU's decision to come up with local solutions to fighting UCGs should be welcomed, from the perspective of MLG it also has potentially worrisome implications. Art. 4(h) not only violates the prohibition on the use of force enshrined in Art. 2(4) of the United Nations (UN) Charter, but also represents a bold challenge to the UN Security Council's (UNSC) primary responsibility for the maintenance of international peace and security, thus undermining the coherence of the international legal order.

In order to prevent the abuse of the anti-UCG norm, a specification of the exact content of this right is imperative. What remains contested, for instance, is the relationship between the different authorities involved in global and regional governance (including the UNSC, the AU Peace and Security Council as well as the decision-making organs of the Regional Economic Communities (RECs)). As a result, global, regional and sub-regional actors in Africa are pursuing approaches to UCG that are sometimes contradictory, thereby sending mixed signals to those who they seek to hold accountable (Lanz and Gasser, 2013: 15).

This article therefore explores the implications of multi-level approaches to fighting UCGs for the rule of law. This aspect has thus far remained under-researched in the debate about the ACDEG in general and the more specific issue of UCGs, and therefore deserves closer examination. I will first scan the literature on MLG for hypotheses regarding how the proliferation of levels of governance and normative orders affects the rule of law. I will then sketch how international law has historically determined the legitimacy of regimes, which is necessary in order to grasp the innovative nature of African conceptions of governmental legitimacy. Afterwards, I will test the hypotheses developed in the second section against a recent case of UCG, namely the 2016/2017 constitutional crisis in The Gambia. Tentative scope conditions will then be derived inductively, 
which explain why MLG sometimes undermines the rule of law and why at other times it does not - something that the existing literature on MLG has thus far failed to do.

The Gambia was selected because it represents both an atypical and an extreme case: It is atypical in that it was one of those rare instances of a UCG in Africa where the international community was unified and effective in restoring the rule of law after an unconstitutional seizure or retention of power. This was possible because actors from different layers of governance - the UN, AU and Economic Community of West African States (ECOWAS) - converged in their assessment of the situation. When compared to other cases of UCGs in Africa, including high-profile cases such as Egypt, but also geopolitically less relevant cases including Madagascar, Guinea-Bissau or Togo (for a more detailed analysis see for example Bamidele and Ayodele, 2018; Leininger, 2014; Nathan, 2016; Souaré, 2014), the unity of purpose displayed by organizations from different levels of governance in response to the Gambian crisis was remarkable.

Choosing such an atypical case for analysis will therefore teach us a lot about the relevant scope conditions under which multi-level responses to UCGs will strengthen the rule of law and under which conditions they will fail to do so. The case of The Gambia suggests that an agreement about the rules of the road regulating how the different layers of governance interact and the definition of a common purpose strengthen the rule of law at the domestic level. Such unity of purpose, in turn, is easier to attain if the (geo)political stakes of a crisis are low, the prospects of success of a military intervention high, and if the perpetrators of the UCG have forfeited their legitimacy both within and outside the region, which shrinks their space for diplomatic manoeuvre and, thus, their ability to use forum shopping for their benefit.

The second rationale for case selection was that the international response to the Gambian UCG can be considered an extreme case, where military forces were employed as the ultima ratio to rectify the unconstitutional retention of power by President Jammeh. ECOWAS' intervention in The Gambia is somewhat reminiscent of the international military response to the UCG in the Ivory Coast, where the incumbent President Laurent Gbagbo had refused to cede power to his legitimate successor Alassane Ouattara after having lost the 2010 elections. In a 'remarkable display of diplomatic consensus' (Bassett and Straus 2011: 131) the international community decided to enforce the results of the elections, militarily, if necessary, and thus helped install Ouattara as the legitimate President. Both the cases of the Ivory Coast and The Gambia represent the most radical approach to enforcing the injunction on UCGs, by military means as a last resort. As such they raise critical issues from a rule of law perspective, which is why it makes sense to focus on such an extreme case for the purposes of this analysis. However, whereas in the case of the Cote d'Ivoire, the UNSC unambiguously authorized the use of force and thus gave legal cover to this pro-democratic intervention although the scope of the mandate was contested (see, for example, Tzanakopoulos 2011), it failed to do so in the case of The Gambia. I thus decided to focus on The Gambia rather than Cote d'Ivoire because ECOWAS' unauthorized intervention nicely illustrates the ambivalent rule of law implications of a multi-level response to UCGs: While the interaction of different layers of governance did contribute to upholding the rule of law at the national level - by enforcing the results of the Gambian election - it ended up undermining the rule of law at the global level because it violated a foundational norm of international law, namely the UN Charter's prohibition on the use of force.

\section{Theoretical framework: MLG and the rule of law}

Despite a voluminous literature on MLG, few authors have studied the relationship between MLG and the rule of law. While a few scholars have speculated about this relationship, the hypotheses that have been put forward are (a) partly contradictory, and (b) have rarely been subjected to 
empirical testing. In order to address this gap, in the following section, I will present a number of hypotheses that shed light on the relationship between MLG and the rule of law, and subsequently apply these to the case of The Gambia in order to strengthen the evidentiary foundations of a debate that has thus far largely been conducted in an empirical vacuum. I will also suggest tentative scope conditions under which the various hypotheses hold.

MLG scholars emphasize the heterarchical constitution of global governance, in which governance functions are dispersed across different actors at different levels and in which different normative orders coexist and potentially compete (Hooghe and Marks, 2003; Tamanaha, 2008). Some authors hold that MLG equally includes elements of hierarchy. ${ }^{2}$ The concept of MLG initially emerged from European integration research, where scholars sought to come up with a new analytical framework in order to grasp the shifts in governance that had occurred in Europe after World War II, and was subsequently extended to the study of other post-Westphalian governance arrangements (see for example Bache and Flinders, 2004; Benz, 2007; Hooghe and Marks, 2003; Jachtenfuchs and Kohler-Koch, 1995; Scharpf, 2001). More recently, MLG scholars have studied how the multi-level nature of contemporary peace operations affects their performance, how 'this complex web of organizational structures evolves, how various organizations are coordinated, and how organizations cope with political dependencies and trade-offs' (Junk, 2012: 247).

One element commonly associated with the rule of law is a system of checks and balances. The question of who guards the guardians is a central concern of constitutional lawyers, a concern that, in the domestic sphere, is reflected in the separation of powers, in order to avoid the concentration of authority in the hands of a few. Even though no such separation of powers exists globally, the dispersion of authority has the potential to hedge the exercise of political power and promote the accountability of power holders (Rosenau, 2000: 195).

How exactly these checks and balances operate, and to what extent they are successful in subjecting political actors to the rule of law remains an open question. MLG theorists tend to take comfort in the aphorism that 'there is safety in numbers', meaning that 'the more pluralistic and crowded the global stage gets' the less any single actor can dominate others (Rosenau, 2004: 46). However, we would be deluding ourselves by believing that the sheer heterogeneity of actors and preferences that comes with the proliferation of governance arrangements will prevent abuses of political power and automatically ensure that the law, not politics, reign supreme.

Instead, the relationship between MLG and the rule of law is too complex to warrant sweeping conclusions. In contrast to optimists like Rosenau, who believe that the checks and balances introduced by MLG contribute to a limitation of power, MLG sceptics argue that the dispersion of authority and the lack of an overarching framework make governance failures more likely (Jessop, 2004: 61).

The answer to the question of whether MLG promotes or undermines the rule of law thus partly hinges on the concept of the rule of law one holds. The rule of law is often associated with a variety of desirable elements. These include not only legal certainty, consistency, predictability, etc., but also substantive human rights norms (civil and political and sometimes even economic, social and cultural rights), and occasionally even procedures for public contestation (for an overview see Tamanaha, 2004: 91-113). Some of these elements may conflict with one another: While many rule-of-law theorists emphasize formal criteria such as legal certainty, stability and predictability (see, for example Raz, 1977), others view the rule of law as requiring that 'public institutions should sponsor and facilitate reasoned argument in human affairs. But argument can be unsettling and the procedures we cherish often have the effect of undermining the predictability that is emphasized in the formal side of the ideal' (Waldron, 2008: 7). Those who associate the rule of law above all with legal certainty and the stabilization of normative expectations will thus view the coexistence of multiple loci of authority, and the potentially ensuing normative conflicts, as a threat to the 
rule of law (see, for example, Baquero Cruz, 2008: 414). Legal pluralists ${ }^{3}$ in turn tend to view the parallel existence of normative orders and loci of authority as normatively desirable, 'both as a source of alternative ideas and as a site for discourse among multiple community affiliations' (Berman, 2007: 1155).

Another ambivalent characteristic of MLG is that it provides opportunities for forum shopping, which is generally seen in negative terms, because it gives violators of the law the possibility to shop around for a forum that imposes the least constraints or sanctions on them and thus enables them to evade accountability. ${ }^{4}$ Lanz and Gasser, for instance, caution that in multi-level mediation processes during constitutional crises parties often 'shop around' for the mediator who offers the most lenient treatment, which 'undermines the leverage of the lead mediator as the parties will be tempted to abandon the process when they are faced with tough decisions' (Lanz and Gasser, 2013: 3).

Others have demonstrated, however, that the simultaneous availability of multiple access points provided by MLG might actually enhance the leverage of actors seeking to strengthen the rule of law: In her study on human rights safeguards in World Bank operations, Monika Heupel (2016) demonstrates how the multiplicity of access points facilitated the efforts of actors seeking to subject the World Bank to a more rigid rule of law constraints. Thus, whether or not forum shopping hedges the exercise of political power therefore depends on which actors are in a position to use these various fora, and for which purposes: actors seeking to avoid accountability will obviously benefit from forum shopping differently than actors seeking to strengthen accountability.

MLG may also lead to institutional rivalries among actors from different levels of governance. The problem of turf wars is especially acute when there is no clear order of precedence among them. And, even if on paper there is a clear hierarchy among these organizations (the UN Charter's codification of UNSC primacy is a case in point), this may not be implemented in practice. If the different actors involved in promoting and protecting the rule of law cannot agree on a coordinated approach, and if there is no superior instance that is able to impose a unified stance, this will send mixed messages to those they seek to hold accountable for violations of the law. Also, if these actors each subscribe to different normative frameworks, this undermines legal certainty, consistency and predictability, which are core elements of a procedural notion of the rule of law.

In summary, the relationship between MLG and the rule of law is as ambivalent as it is underresearched. In the following passage, I will condense the preceding discussion into a set of general hypotheses, which I will later test against the empirical evidence of the Gambian crisis. Since, as has been shown above, the existing literature disagrees on the implications of MLG for the rule of law (with some authors expecting beneficial effects and others detrimental ones) I decided to formulate two competing hypotheses for each causal relationship that I will investigate in the case study below. This framing adequately reflects the state of the art on the subject, which is characterized by contradictions and uncertainties regarding the relationship between MLG and the rule of law. Based on the empirical evidence I will, moreover, identify a tentative set of scope conditions explaining under which circumstances MLG undermines or strengthens the rule of law, respectively.

H 1a: MLG's system of checks and balances facilitates the limitation of power. ${ }^{5}$

H 1b: MLG's system of checks and balances does not facilitate the limitation of power.

H 2a: Forum-shopping opportunities offered by MLG undermine accountability. ${ }^{6}$

H 2 b: Forum-shopping opportunities offered by MLG do not undermine accountability. 
H 3a: MLG hinders concerted efforts to hold power-holders to account because of institutional rivalries. ${ }^{7}$

H 3b: MLG does not hinder concerted efforts to hold power holders to account.

$\mathrm{H}$ 4a: The proliferation of normative frameworks in MLG undermines legal certainty and predictability. ${ }^{8}$

$\mathrm{H} 4 \mathrm{~b}$ : The proliferation of normative frameworks in MLG does not undermine legal certainty and predictability.

\section{Regime legitimacy in international law: a historical perspective}

In order to appreciate the changes that have taken place in the assessment of governmental legitimacy in Africa - changes that are reflected, inter alia, in the ACDEG's provisions on UCGs - one has to understand how governmental legitimacy used to be defined. During the Cold War, a government's internal practices - its democratic credentials, human rights' record and (non-) adherence to the rule of law - were of no or little interest to the international community. Governmental legitimacy depended solely on it exercising effective control over a given piece of territory. This general agnosticism with regard to the internal practices of governments ${ }^{9}$ was also reflected in the policies of international organizations. International organizations including the UN, but also regional organizations such as the Organization of African Unity, consistently refused to make their assessment of governmental legitimacy contingent upon any substantive normative standards.

As an organization based on the principle of equivalence of regimes, the UN seemed an unlikely candidate for promoting a specific concept of governmental legitimacy based upon specific modes of internal governance. Agnosticism regarding the internal practices of its members pervaded not only the UN's recognition and admission practices, but also informed the organization's rules on intervention, which provide for the sovereign equality of member states, their rights to noninterference and non-use of force (Art. 2(1), 2(4), and 2(7)), and allow for only two narrowly circumscribed exceptions to the prohibition on the use of force, namely the right to self-defence (Art. 51) as well as enforcement action authorized by the UNSC (Art. 42).

The latter became increasingly activist, however, after the end of the Cold War, authorizing for instance intervention in response to a military coup in Haiti, which had led to the overthrow of the democratically-elected government of Bertrand Aristide. Regional organizations equally began to demand (and enforce) democratic governance, with ECOWAS intervening in Sierra Leone in order to reinstall the democratically-elected government of President Kabbah, even though the latter had lost effective territorial control and was, therefore, technically not legitimized to invite foreign intervention on his behalf.

In the past decade or so, this trend has accelerated, with the Organization of American States (OAS) and the AU adopting norms against 'unconstitutional changes of government' or 'interruptions of constitutional order' (OAS). Even the Arab League (LAS) - an unlikely candidate for enforcing standards of good governance - has taken cautious first steps towards demanding that its members satisfy certain minimal standards of governance. While Art. 8 of the LAS Pact demands that '[e]very member State of the League shall respect the form of government obtaining in the other States of the League ... and shall pledge itself not to take any action tending to change that form', the League swiftly imposed sanctions against the regimes in Libya and Syria that violently suppressed popular will. These sanctions were unprecedented in the League's history, which had never before penalized a member-state for its internal practices (Maddy-Weitzman, 2012: 73).

Another traditionally anti-interventionist organization, the Association of Southeast Asian Nations (ASEAN) has at least on paper begun to acknowledge the importance of respect for 
democracy, human rights and the rule of law. The ASEAN Political and Security Community stresses the importance of including democracy and human rights promotion into ASEAN's objectives - a decision which has been considered 'historic' (Sukma, 2009: 4). In summary then, the internal practices of states are increasingly being subjected to external scrutiny, as the following section on multi-level responses to UCGs in Africa demonstrates.

\section{Multi-level approaches to countering UCGs in Africa: three layers of governance}

In comparison to their counterparts in other regions of the world, African (sub-)regional organizations have adopted relatively far-reaching policies aimed at promoting and protecting certain standards of internal governance in member states. When it comes to responding to constitutional crises in Africa, usually a number of players from different layers of governance - the global, regional and sub-regional, and national - interact, making democracy protection a 'crowded field' (Lanz and Gasser, 2013) where a clear division of labour is often absent. The respective actors' underlying normative frameworks do not always converge, and naturally political preferences and incentive structures differ as well. In the following, I will take a closer look at the respective organizations' normative frameworks, before exploring how these frameworks have been applied in the case of The Gambia.

Until about a decade ago, the UN was not very active as a mediator during constitutional crises in Africa, and it only became involved after regional and sub-regional organizations began to develop norms and policies in order to address unconstitutional changes of government. The AU as well as some of the sub-regional organizations - seeking to signal their commitment to democracy and the rule of law and other universally cherished values - have adopted a blanket prohibition of UCGs. These are defined in Art. 23 of the ACDEG as including the following situations:

- a military coup d'état against a democratically elected government;

- intervention by mercenaries to replace a democratically-elected government;

- replacement of a democratically-elected government by armed rebel movements;

- the refusal of an incumbent government to relinquish power after free and fair elections; and

- any amendment or revision of the constitution or legal instruments, which is an infringement on the principles of democratic change of government.

The Democracy Charter must be read in conjunction with the protocol establishing the AU Peace and Security Council, which, in Art. 7(g) provides for the imposition of sanctions on a regime that has come to power through unconstitutional means (African Union Assembly, 2002). Moreover, the perpetrators of a UCG are not allowed to participate in elections that are held after a coup to restore constitutional order and 'may be tried before the competent court' (Art. 25 of the ACDEG): in this case, before the African Court on Justice and Human Rights, which is not yet in existence, however.

While the AU's approach to UCGs articulates a relatively precise vision of how power is to be transferred, it leaves important issues regarding the exercise of political power unaddressed. It has often been pointed out that in a situation of poor governance and repression, it becomes difficult, if not impossible, for citizens to exercise their democratic rights in a lawful fashion, thus making a coup d'état the only alternative route to get rid of undemocratic leaders who have lost their popular legitimacy (see, for example, Ikome, 2007). The question of popular uprisings possibly constituting an exception to the injunction on UCGs became especially salient in the context of the Arab Spring, which posed an acute challenge for the AU's approach to UCGs. 
The High-Level Panel on Egypt therefore recommended development of criteria to determine when a popular uprising does not fall within the ambit of the ACDEG's prohibition of UCGs:

(a) the descent of the government into total authoritarianism to the point of forfeiting its legitimacy; (b) the absence or total ineffectiveness of constitutional processes for effecting a change of government; (c) popularity of the uprisings in the sense of attracting a significant portion of the population and involving people from all walks of life and ideological persuasions; (d) the absence of involvement of the military in removing the government; (e) peacefulness of the popular protests (African Union Peace and Security Council, 2014: 31).

Another innovative feature of African approaches to UCGs is that the AU and some of the RECs, such as the Southern African Development Community (SADC) and ECOWAS, have given themselves a right to intervene militarily in the event of threats to constitutional governance. ${ }^{10}$ As will be discussed in more detail in the fifth section, these provisions raise thorny issues for the rule of law in global governance, as the UN Charter emphasizes the primacy of the UNSC in Art. 53, according to which 'no enforcement action shall be taken under regional arrangements or by regional agencies without the authorization of the Security Council'. As discussed earlier, theorists of MLG distinguish between type I and type II governance, and the relationship between the UN and (sub-)regional organizations reflects a vertically ordered system of governance (type I), as evidenced not only by Art. 53 of the UN Charter, but also by Art. 103, which establishes the primacy of the UN Charter over other international treaties, and Art. 25, which stipulates that ' $[\mathrm{t}] \mathrm{he}$ Members of the United Nations agree to accept and carry out the decisions of the Security Council in accordance with the present Charter'. These provisions combined give the Security Council 'crude supranational power over member states' (White, 2007: 142). According to Art. 103, Art. 2(4) of the UN Charter would thus supersede Art. 4(h) of the AU Act. Furthermore, considering the jus cogens nature of Art. 2(4), a case could be made that Art. 4(h) and possibly the AU Act as a whole are null and void, since, according to Art. 53 of the Vienna Convention on the Law of Treaties, agreements that conflict with a peremptory norm of international law are invalid.

In contrast to the $\mathrm{AU}$ and some of the sub-regional organizations, the $\mathrm{UN}$ does not reject all UCGs per se, but rather approaches the issue on a case-by-case basis. The UN's policy takes into account factors such as popular support for a given coup d'état, the incumbent regime's governance record, the credibility of the coup plotters, etc. There are no automatic sanctions against the perpetrators of unconstitutional changes of government, which has given the UN flexibility in dealing with coups d'état and mediating after contested elections. Also, the UN Charter lays down a clear prohibition on the use of force in Art. 2(4) and thus does not envisage a right to pro-democratic intervention (unless, of course, it has been authorized by the UNSC).

In 2012, the UN Secretary-General issued a report on Guidance for Effective Mediation that was endorsed by the General Assembly and can be viewed as the normative basis on which the UN addresses constitutional and democratic challenges in member states (United Nations, 2012). The report states that mediators must work in conformity with applicable international law, but also emphasizes flexibility, impartiality, inclusivity, national ownership and consent by the parties. Instead of rejecting UCGs as a matter of principle, the UN report advises mediators to 'balance the need to adhere to international norms without overtly taking on an advocacy role' (United Nations, 2012: 17).

In sum, a comparison of the different organizations and their approaches to the problem of UCGs suggests that there is considerable potential for institutional competition and norm collisions. The risk of conflict is especially high at the level of secondary rules of implementation, which regulate who is authorized to respond to a UCG, and by what means. As the following case 
study shows, MLG does not inevitably produce institutional rivalries that undermine the effectiveness of anti-UCG initiatives at the domestic level. Yet the case study also demonstrates that MLG often gives rise to norm collisions, which in turn undermine the rule of law at the global level.

\section{The case of The Gambia}

In late 2016, the people of The Gambia voted the country's long-running authoritarian leader, President Yahya Jammeh, out of power in what observers called an 'electoral earthquake' (Kora and Darboe, 2017). The result was endorsed by ECOWAS, the AU and the UN, yet Jammeh refused to transfer power to his legitimate successor Adama Barrow, which constitutes a violation of Art. 23(4) of the ACDEG. The AU PSC reacted by threatening all necessary measures to ensure Jammeh would give up power (African Union Peace and Security Council, 2016), and ECOWAS did the same (Economic Community of West African States, 2016). The UNSC later commended ECOWAS' position (United Nations Security Council, 2017a), even though the threat of force was technically speaking illegal.

Unlike other constitutional crises in Africa, where the losers of the elections were placated with power-sharing agreements, ECOWAS declined such a compromise and instead decided to enforce the results of the Gambian elections - militarily, if necessary (Dersso, 2017). After Jammeh proved immune to diplomatic initiatives trying to persuade him to leave office, ECOMIG forces entered The Gambia, and shortly thereafter Jammeh agreed to step down. ECOMIG's goals to enforce the rule of law in The Gambia and facilitate the inauguration of the legitimate President Adama Barrow were thus attained.

Now, how do the hypotheses identified in the second section above fare when tested against the facts of this case? H la about checks and balances is confirmed, because rule of law deficits at the domestic level were compensated for by the intervention of actors from higher levels of governance. The international response to the UCG in The Gambia is an excellent example of how concerted action involving organizations from the sub-regional, regional and global levels, who had a relatively homogeneous set of preferences, safeguarded democracy and the rule of law at the national level. This alignment of preferences is an important prerequisite for the success of multilevel responses to UCGs. If such unity of purpose does not exist, rule of law deficits at the national level are unlikely to be compensated for by intervention from higher levels of governance, as other cases of UCG in Africa have shown (see for example Nathan, 2013).

Regarding H 2a about opportunities for forum shopping, it is not known whether Jammeh tried to shop around for a lenient treatment; but at any rate, if he did try it certainly did not work out, because there was consensus at all governance levels that Jammeh ought to accept the results of the elections and transfer power to his legitimate successor. $\mathrm{H} 2 \mathrm{~b}$ is thereby confirmed, although one would want to add the qualifier 'necessarily': yes, MLG does offer forumshopping opportunities, but this does not necessarily undermine accountability if, again, those responding to a UCG can build consensus on not allowing the forum shopper to avoid the constraints of the law.

$\mathrm{H} 3 \mathrm{a}$ about MLG producing institutional rivalries, which in turn hinder concerted efforts to hold power-holders to account, is invalidated. The case of The Gambia demonstrates that MLG does not necessarily have to give rise to institutional competition, if actors can agree on a clear division of labour, an order of precedence and a common purpose. The AU and the UN allowed ECOWAS to take the lead in organizing the diplomatic and later military response to the crisis. Again, this was only possible because of the alignment of preferences among these actors.

$\mathrm{H} 4 \mathrm{a}$ about the proliferation of normative frameworks undermining legal certainty and predictability is confirmed as well, because the threat and subsequent use of force undermined 
fundamental global norms and challenged the coherence of the international legal order. I will return to this issue later.

Now, hypotheses $1 \mathrm{a}, 2 \mathrm{~b}$, and $3 \mathrm{~b}$ depend for their operation on a certain prerequisite, namely the unity of purpose among actors from different levels of governance. Such unity of purpose is in turn facilitated by a number of scope conditions, which I will discuss in greater detail below.

The case of The Gambia demonstrates that MLG does not necessarily have to produce institutional rivalries, if actors can agree on a clear division of labour and an order of precedence. The AU and the UN allowed ECOWAS to take the lead in organizing the diplomatic and later military response to the crisis. Such inter-organizational consensus is easier to construct when the geopolitical stakes of a given crisis are relatively low, the prospects of a successful military intervention are high, and none of the actors involved have a vested interest in protecting the perpetrator of the UCG. In the case of The Gambia, the relatively small size of the Gambian army, Nigeria's and Senegal's leadership on the issue and Jammeh's lack of powerful allies in the region and elsewhere made a concerted response to Jammeh's abuse of power possible (Hartmann 2017: 85).

In particular, Jammeh's political isolation seems to be a (if not the most) significant factor in explaining the swiftness of the international response to the Gambian UCG: As Kora and Darboe (2017: 149) point out, Jammeh's relations with the international community at large had already been strained 'to the breaking point' even before the 2016 elections. Neither could Jammeh, Africa's 'loneliest despot' (Hunt and McCormick, 2017) count on the backing from his peers in the region, as he had turned into 'an embarrassment for the regional leaders, not primarily because of his repressive rule, but due more to his erratic personal behavior' (Hartmann, 2017: 93). His relationship with ECOWAS was tense, because Jammeh was angered by never having been given the organization's rotating chairmanship and had moreover vetoed ECOWAS's 2015 resolution on term limits, which 'had bred hard feelings between him and leaders of nearby countries' (Kora and Darboe, 2017: 154).

Jammeh had alienated his neighbour Senegal, in particular, by supporting separatist groups in the Casamance region (Hunt and McCormick, 2017). Senegal thus had strong motives for removing Jammeh from power and thus pushed for ECOWAS' involvement in the crisis, but also took the lead at the UN in drafting Resolution 2337. Senegal's efforts were supported by regional hegemon Nigeria, which assumed a leadership role in the crisis 'without any clear material interests in the small country' (Hartmann, 2017: 94). Nigeria's role is nonetheless somewhat ambivalent: Governments in West Africa, Nic Cheeseman points out, 'like to demonstrate their democratic credentials by pushing democracy in the region' (quoted in Hunt and McCormick, 2017). This corresponds to a broader 'pattern in which Nigeria has consistently held other West African states to standards that it has not always lived up to itself' (quoted in Hunt and McCormick, 2017).

To sum up, the fact that some of ECOWAS' most powerful members had allied with the AU and the UN in pushing for Jammeh's departure from the presidential office contributed to the limitation of power (H 1a) shrank Jammeh's diplomatic space for manoeuvre and thus his ability to forumshop ( $\mathrm{H} 2 \mathrm{~b}$ ), and reduced the potential for institutional competition (H 3b). The first three hypotheses thus share a similar set of scope conditions that have less to do with legal factors and more to do with the political context of the intervention.

These scope conditions are also relevant to the operation of $\mathrm{H} 4 \mathrm{a}$, the consequences of which I will discuss in more detail in the following section. In the absence of a world government consistently sanctioning any deviations from the norms of the UN Charter, non-compliance will occur - as demonstrated by ECOWAS' illegal yet legitimate intervention. However, instead of protecting the integrity of the UN Charter at all costs, the Security Council decided to welcome the intervention, which in turn was only possible because none of the permanent members had major political stakes in the Gambian crisis and because Jammeh had become an international pariah. 
Thus, one could view The Gambia case as an example of how multi-level approaches to countering the unconstitutional retention of power can contribute to restoring the rule of law at the national level - if the political circumstances are auspicious. The UN and the AU, in the name of subsidiarity, deferred to ECOWAS' leadership role, but here is the catch: the ECOWAS use of force, all the while being welcomed for political reasons, was technically in violation of Art. 2(4) of the UN Charter. While UNSC Resolution 2337 expressed support for ECOWAS' efforts, it does not authorize the use of force. In UN lingo, the clause 'all necessary means' constitutes a mandate for military intervention, yet Resolution 2337 does not use this phrase. Instead, it welcomes ECOWAS's commitment to ensure 'by political means first, the respect of the will of the people of The Gambia' (United Nations Security Council, 2017a).

In order to understand what is meant by this opaque phrase, it is important to look at the drafting history of the resolution and subsequent explanations by UNSC members who voted on the resolution. Apparently, the original draft of the resolution, tabled by Senegal, contained the phrase 'any necessary means' but the clause was later deleted after some UNSC members had objected to it (What's in Blue, 2017). Russia was especially uneasy, apparently, with the phrase 'all necessary means' (What's in Blue, 2017).

The fact that the resolution does not refer to Chapter VII of the UN Charter also underlines that it was not meant to be read as an authorization to use military force, as do the statements made by UNSC members after the adoption of the resolution. Uruguay, for instance, invoked Art. 53 of the UN Charter, emphasizing that UNSC approval for enforcement action by regional organizations ought to be 'express[ive], affirmative and prior' and that nothing in the resolution 'should be interpreted as express authorization of the use of force' (United Nations Security Council, 2017b). Bolivia echoed this view, stressing that Resolution 2237 'cannot and should not be interpreted to represent Security Council support for or endorsement of the use of force. To that end, we would need a specific resolution providing such a mandate or endorsing such action' (United Nations Security Council, 2017b). Egypt in turn explained that it was

anxious to see the inclusion in the resolution of wording reflecting one of the most important purposes and principles of the Charter of the United Nations, which is the peaceful settlement of disputes. We believe that efforts to achieve that should be exhaustive if we are to avoid chaos and uphold the principles of international law. However, in the light of the last amendment to the draft, which underlined the importance of a political settlement of the impasse in The Gambia, we are convinced that today's resolution does not endorse any mandatory automatic enforcement, as such processes require the Security Council's clear and unquestioned authorisation, in accordance with Chapter VIII of the Charter of the United Nations (United Nations Security Council, 2017b).

The fact that the Council nonetheless welcomed ECOWAS' military intervention suggests that the legal basis for the intervention 'is to be found outside the system of collective security established by the UN Charter' (Kreß and Nussberger, 2017: 244), leaving the right to intervention by invitation as the only remaining possible legal rationale for ECOWAS' operation. However, as explained earlier, international law, at this point, does not know a right to request the use of force by a president in exile who has never been in effective control of the state in question. Thus, by intervening without either a legitimate invitation from the host state or a UNSC mandate, ECOWAS' use of force - all the while bolstering the rule of law domestically - violated the rule of law internationally, because an organization from a lower level of governance arrogated to itself powers that were reserved to an authority at a higher level of governance.

It is important to note, however, that in the progressive development of international law, a breach of the law may already contain the seeds of a new rule. The case of The Gambia might 
therefore possibly trigger an expanded understanding of the concept of intervention by invitation to include invitations issued by heads of state who are not, and never have been, in effective control of 'their' state. Kreß and Nussberger, for instance, suggest that the UNSC's endorsement of Barrow as the legitimate President of The Gambia could furnish 'a further precedent for the willingness of the international community to give precedence to democratic legitimacy over the effective control of government in a small number of borderline cases' (2017: 250).

Although state practice is not (yet) uniform, there is some evidence to support this view: After the adoption of Resolution 2337, Russia's Ambassador to the UN explained to the press that should political means to resolve the crisis fail, Barrow could request military assistance (Lederer, 2017), indicating Russia's acceptance of the notion that a democratically-elected head of state who has never been in effective control of the state in question is nonetheless entitled to invite foreign military assistance. Britain's Deputy UN Ambassador equally declared that 'it's very clear that if president Barrow asks for assistance, then that's something as the legitimate president of Gambia he's perfectly entitled to do' (quoted in Lederer, 2017). Whether or not these particular views expressed by Russia and the UK are indicative of the emergence of a new intersubjective consensus on a broadened conception of the right to intervention by invitation remains to be seen.

\section{Policy implications}

While the international response to the UCG in The Gambia raises thorny issues from an international legal perspective, politically the intervention can be considered a success story. The multilevel response to the Gambian UCG represents a good example of how potential pitfalls of MLG can be addressed by adherence to the principle of subsidiarity. However, this does not mean that subsidiarity is a panacea for all cases of UCG, because subsidiarity means different things to different people.

While the AU strongly favours subsidiarity in UN-AU relations, it does not always embrace subsidiarity in AU-REC relations (Nathan, 2016: 10). The UN in turn finds subsidiarity attractive unless a specific crisis is of geopolitical relevance, in which case the primacy of the UNSC is emphasized (Nathan, 2016). The UCG in The Gambia certainly did not fall into this category. The AU argues that subsidiarity lies at the heart of Chapter VIII of the UN Charter, yet as explained earlier, this does not detract from the necessity to first seek a UNSC mandate. Thus, an important first step towards a shared AU-UN approach would be to seek agreement on what exactly is meant by 'an innovative and bold approach to applying the spirit of Chapter VIII' demanded by the AU (African Union Peace and Security Council, 2012). A step in the right direction was the establishment of the UN Office to the AU (UNOAU). In 2014 UNOAU and the AU Peace and Security Department developed the Joint UN-AU Framework for an Enhanced Partnership in Peace and Security which seeks to make UN-AU interactions more systematic and effective (unpublished document referenced in Nathan, 2016: 5).

The rules of the road in UN-AU relations in matters of peace and security are as contested as in AU-REC interactions, which are governed by the 2002 Protocol on the PSC (African Union Assembly, 2002). Art. 16 of the Protocol stipulates that the RECs are part of the security architecture of the AU, which has the primary responsibility for the maintenance of peace. This implies that the AU and the RECs exist in a hierarchical relationship, with the AU being the superior body. Yet as Laurie Nathan (2016: 6) points out, the situation is more complicated than this, as the RECs are independent legal entities, governed by their own charters, and they are not formally subordinate to the AU. Another important document on AU-REC interactions is the 2008 memorandum of understanding $(\mathrm{MoU})$ on cooperation between the AU and the RECs in the area of peace and security (African Union, 2008). Yet the MoU does not contribute to clarifying the order of precedence 
among the AU and the RECs as it emphasizes the competing principles of AU primacy and subsidiarity. While the establishment of liaison offices has facilitated AU-REC interactions, this does not remedy the fundamental problem of disconnect at the decision-making level, with REC liaison officers complaining that they are being excluded from closed-door AU-PSC meetings (Nathan, 2016: 6). The responsibility for clarifying the relationship between these two levels of governance has been allocated to the Joint Task Force on Strengthening Relations between the AU and the RECs/RMs in the Area of Peace and Security, set up in 2014 (unpublished document referenced in Nathan, 2016: 7), but the practical effects of this remain to be seen.

\section{Conclusion}

Is more really more? This was the question raised at the outset of this contribution. In light of The Gambian experience, the tentative answer would be a 'yes, but only if certain general prerequisites are fulfilled'. These include an agreement of the rules of the road regulating how the different layers of governance interact - subsidiarity v. precedence for organizations from higher levels of governance - and the definition of a common purpose. If these general prerequisites are fulfilled, then multi-level responses to UCGs will lead to strengthening the rule of law at the domestic level, while at the same time potentially undermining the rule of law at the international level. Obviously, a single case-study's potential for producing generalized inferences are rather limited. Hence, more rigorous and comparative research will be necessary.

In particular, the question of specific scope conditions requires further scrutiny. Put differently, what conditions facilitate the definition of a common purpose that was instrumental to the effectiveness of the multi-level response to the Gambian UCG? In this article, I suggested that The Gambia's lack of geopolitical relevance, the high prospects of success of a military intervention and Jammeh's decaying legitimacy within and beyond the region facilitated the building of consensus across different layers of governance. This consensus in turn reduced the likelihood of institutional rivalries among ECOWAS, the AU and the UN; it helped the multi-level system of checks and balances to kick in; and, finally, it prevented Jammeh from shopping around for a forum that would have condoned his anti-democratic behaviour.

Now, these factors can be largely attributed to a rationalist theoretical framework. They leave open the question about the compliance pull of the anti-UCG norm. Put differently, did the fact that ECOWAS had codified a right to pro-democratic intervention have any independent socializing effect on the actors involved? Was the concerted response to the UCG due to the compliance pull of the anti-UCG norm or did it just 'work out incidentally by an extra legal commitment to coherent action'? ${ }^{11}$ For instance, did the existence of this norm prompt Senegal and Nigeria to take the lead in organizing the military response to the crisis? Did the existence of this norm contribute to Jammeh's eroding regional legitimacy? Did the existence of this norm prompt the AU and the UN to acquiesce in ECOWAS' pro-democratic intervention?

And if the answer to all these questions is yes, should we thus expect a replication of the Gambian scenario in a situation where the (geo)political stakes are less favourable, where, for instance, the perpetrator of the UCG enjoys backing from powerful actors within or outside the region? Answering these questions in a methodologically rigorous fashion would obviously go beyond the scope of this article, because it would require a detailed reconstruction of the internal dynamics of the decision-making processes at all levels of governance, in order to isolate the independent influence of the anti-UCG norm from other variables.

At least for one of the actors studied here, ECOWAS, there is some evidence in the literature that its members had made a more or less principled commitment to upholding the anti-UCG norm: 
The fact that so many of the countries that played key mediation roles in Gambia are - or at least see themselves as - functioning democracies highlights another lesson with broader relevance in Africa: Where the interests and values of regional powers are aligned, enabling them to act in concert, they are much more likely to succeed (Hunt and McCormick, 2017).

This view is echoed by Hartmann, who maintains that most West African governments had come to power through defeating incumbents in elections, and thus made a principled commitment to upholding the electoral process as the only legitimate means of transferring political power (Hartmann, 2017: 95). The factor democratic density (the percentage of democracies within a regional organization) thus seems to shape the organization's response to the problem of UCGs, which in turn explains why ECOWAS is ahead of other (sub-)regional organizations in Africa in fighting UCGs (Hartmann, 2017). Whether the AU and the UN share the same principled commitment to the injunction on UCGs, however, remains an open question. Whereas this contribution was focused more on the effects of multi-level responses to UCGs (on the rule of law in particular), future research should take a closer look at the causes of such responses, including the socializing effect of norms.

\section{Funding}

The author disclosed receipt of the following financial support for the research, authorship, and/or publication of this article: The research was funded by a grant from the Thyssen Foundation, grant no. AZ 20.15.0.073.

\section{Notes}

1. However, one should nonetheless be clear about what the rule of law is not, namely rule by law (see, for example Ginsburg, 2012). Rule by law means ruling as per the law. Many authoritarian rulers have used the law to provide a veneer of legitimacy to their repressive practices - apartheid-South Africa is a case in point. The core difference between the rule of law and rule by law is that the former implies the ability of law to impose meaningful limits on the exercise of political power and thus includes the idea of a government of laws, the notion of the supremacy of the law, and the requirement of equality before the law (Peerenboom, 2002: 9). Rule by law, by contrast, 'refers to an instrumental conception of law in which law is merely a tool to be used as the state sees fit' (Peerenboom, 2002).

2. There is no agreement in the literature regarding the question whether MLG is necessarily heterarchical or whether it may also include vertically ordered spheres. While Schmitter and Kim, for instance, write that MLG is defined by the absence of a stable hierarchy across levels of governance (2005: 5), Benz holds that MLG is characterized by a mixture of vertical and horizontal forms of governance (2004: 27). Hooghe and Marks in turn distinguish between types I and II governance, with the former being characterized by vertical relations (2003: 239) and the latter being defined by the absence of hierarchy (2003: 238) - corresponding to what Griffith calls 'strong' legal pluralism (1986: 5).

3. Part of this body of research has explored the relationship between global legal pluralism and the rule of law - see, for instance, the special issue by Turkuler Isiksel and Anne Thies in Global Constitutionalism (2013); Heupel and Reinold's The Rule of Law in Global Governance (2016); Ernst-Ulrich Petersmann's International Economic Law in the 21st Century (2012); as well as Andreas Føllesdal, Ramses Wessel, and Jan Wouters' Multilevel Regulation and the EU (2008).

4. In a system of MLG that displays both horizontal and vertical forms of ordering, forum shopping is legally speaking only allowed in heterarchically organized policy fields, but not in areas where the law imposes a clear hierarchy of normative orders. This of course does not mean that such legal hierarchies are always observed in practice, as the case discussed in this article demonstrates.

5. This applies not only to a higher-level authority checking (or attempting to check) a (supposedly) lower level authority, but also vice versa, as well as to horizontally ordered relations. Witness, for instance, the Kadi case, where the European Court of Justice contested the primacy of UNSC resolutions over EU law: Case C-402/05 P and C-415/05, P. Kadi and Al Barakaat International Foundation v. Council and Commission (2008) ECR I-6351. 
6. Vertical and horizontal forum shopping are both possible. The tortuous history of the Hissène Habré case, for instance, involved both forms of forum shopping. For a detailed analysis see Brody, 2015.

7. Institutional competition may arise between authorities from different levels of governance, but may also occur horizontally; again, the Hissène Habré case offers an instructive example, where the victims' advocates, after having unsuccessfully sought Habré's trial in Senegal, turned to Belgium to have him prosecuted there based on the principle of universal jurisdiction (Brody, 2015).

8. This applies to both the national and supranational levels.

9. There are a few exceptions, though, for example apartheid-South Africa, which was widely condemned internationally.

10. According to Art. 4(h) of its Constitutive Act, the AU currently has the right to intervene in the event of serious human rights abuses. In 2003, an amendment was adopted, which has not entered into force, and which would expand the scope of Art. 4(h) to include interventions addressing a 'serious threat to legitimate order' (African Union Assembly, 2003). Art. 25 of the ECOWAS Protocol Relating to the Mechanism for Conflict Prevention, Management, Resolution, Peace-Keeping and Security in turn authorizes ECOWAS to intervene in the event 'of an overthrow or attempted overthrow of a democratically elected government' (Economic Community of West African States, 1999). Finally, the SADC Protocol on Politics, Defence and Security Cooperation in Art. 2 stipulates that SADC shall 'consider enforcement action in accordance with international law and as a matter of last resort...' and must be read in conjunction with Art. 11, which posits that enforcement action shall only be undertaken with the authorization of the UNSC (Southern African Development Community, 2001).

11. I would like to thank the anonymous reviewers for alerting me to this point.

\section{References}

African Union (2000) Constitutive Act of the African Union. Lomé: African Union.

African Union (2008) Memorandum of Understanding on Cooperation in the Area of Peace and Security between the African Union, the Regional Economic Communities and the Coordinating Mechanisms of the Regional Standby Brigades of Eastern and Northern Africa. Addis Ababa: African Union.

African Union Assembly (2002) Protocol Relating to the Establishment of the Peace and Security Council of the African Union. Durban: African Union.

African Union Assembly (2003) Protocol on Amendments to the Constitutive Act of the African Union. Addis Ababa, Maputo: African Union.

African Union Assembly (2007) African Charter on Democracy, Elections and Governance. Addis Ababa: African Union.

African Union Peace and Security Council (2012) Report of the Chairperson of the Commission on the Partnership between the African Union and the United Nations on Peace and Security: Towards Greater Strategic and Political Coherence, PSC/PR/2, (CCCVII). Addis Ababa: African Union.

African Union Peace and Security Council (2014) Final Report of the African Union High-Level Panel for Egypt, PSC/AHG/4, (CDXVI). Addis Ababa: African Union.

African Union Peace and Security Council (2016) Communiqué, PSC/PR/COMM, (DCXLIV). Addis Ababa: African Union.

Bache I and Flinders M (eds) (2004) Multi-Level Governance. Oxford: Oxford University Press.

Bamidele $\mathrm{O}$ and Ayodele $\mathrm{B}$ (2018) In the service of democratic governance: The African union framework on unconstitutional change of government and ECOWAS protocol on good governance and democracy in the post-Arab spring. Journal of Asian and African Studies 53(1): 132-146.

Baquero Cruz J (2008) The legacy of the Maastricht-Urteil and the pluralist movement. European Law Journal 14(4): 389-422.

Bassett T and Straus S (2011) Defending democracy in Cote d'Ivoire. Foreign Affairs 90(4): 130-140.

Benz A (2004) Einleitung: Governance - Modebegriff oder Nützliches Sozialwissenschaftliches Konzept? In: Benz A (ed.) Governance - Regieren in Komplexen Regelsystemen. Eine Einführung. Wiesbaden: VS Verlag für Sozialwissenschaften, pp.11-28.

Benz A (2007) Accountable multilevel governance by the open method of coordination? European Law Journal 13(4): 505-522. 
Berman P (2007) Global legal pluralism. Southern California Law Review 80: 1155-1237.

Brody R (2015) Bringing a dictator to justice: The case of Hissène Habré. Journal of International Criminal Justice 13(2): 209-17.

Call C (2012) UNMediation and the Politics of Transition after Constitutional Crises. New York: International Peace Institute.

Carozza P (2003) Subsidiarity as a structural principle of international human rights law. American Journal of International Law 97: 38-97.

Cass R (2004) Property rights systems and the rule of law. In: Colombatto E (ed.) The Elgar Companion to the Economics of Property Right. Oxford: Edward Elgar Publications, pp.131-63.

Dersso S (2017) Gambia: A lesson for African dictators. Al Jazeera. Available at: http://www.aljazeera.com /indepth/opinion/2017/01/gambia-lesson-african-dictators-170122092224512.html (accessed 20 August 2017).

Donno D (2010) Who is punished? Regional intergovernmental organizations and the enforcement of democratic norms. International Organizations 64: 593-625.

Economic Community of West African States (1999) Protocol Relating to the Mechanism for Conflict Prevention, Management, Resolution, Peace-Keeping and Security. Abuja: Economic Community of West African States.

Economic Community of West African States (2016) Fiftieth Ordinary Session of the ECOWAS Authority of Heads of State and Government, Final Communiqué. Abuja: Economic Community of West African States.

Elvy SA (2013) Towards a new democratic Africa: The African charter on democracy, elections and governance. Emory International Law Review 27: 41-116.

Engel U (2010) Unconstitutional Changes of Government: New AU policies in defence of democracy. Leipzig: University of Leipzig, Working Paper Series of the Graduate Centre Humanities and Social Sciences of the Research Academy Leipzig, No. 9.

European Court of Justice (2008) Case C-402/05 P and C-415/05, P. Kadi and Al Barakaat International Foundation v. Council and Commission, ECR I-6351.

Føllesdal A, Wessel RA and Wouters J (eds) (2008) Multilevel Regulation and the EU: the interplay between global, regional, and national normative processes. Leiden: Martinus Nijhoff.

Ginsburg T (2012) Rule by Law: The politics of courts in authoritarian regimes. Cambridge: Cambridge University Press.

Glen P (2012) Institutionalizing democracy in Africa - a comment on the African charter on democracy, elections and governance. African Journal of Legal Studies 5: 119-146.

Griffiths J (1986) What is legal pluralism? Journal of Legal Pluralism 24: 1-55.

Hartmann C (2017) ECOWAS and the restoration of democracy in The Gambia. Africa Spectrum 52(1): 85-99.

Hunt L and McCormick T (2017) The fall of Africa's loneliest despot. Foreign Policy, 23 January 2017.

Heupel M (2016) Human rights protection in international organizations in the era of multi-level governance and legal pluralism. In: Heopel M and Reinold T (eds) The Rule of Law in Global Governance. Basingstoke: Palgrave, pp.149-179.

Heupel M and Reinold T (eds) (2016) The Rule of Law in Global Governance. Basingstoke: Palgrave.

Hooghe L and Marks G (2003) Unraveling the central state, but how? Types of multi-level governance. American Political Science Review 97(2): 233-243.

Ikome FN (2007) Good Coups and Bad Coups: The limits of the African Union's injunction on unconstitutional changes of power in Africa. Johannesburg: Institute for Global Dialogue, Occasional Paper No. 55.

Isiksel T and Thies A (2013) Introduction: Changing subjects: Rights, remedies and responsibilities of individuals under global legal pluralism. Global Constutionalism 2(2): 151-159.

Jachtenfuchs M and Kohler-Koch B (eds) (1995) Europäische Integration. Opladen: Leske + Budrich.

Jessop B (2004) Multi-level governance and multi-level metagovernance. In: Bache I and Flinders M (eds) Multi-level Governance. Oxford: Oxford University Press, pp.49-74.

Junk J (2012) Organizing peace in a multi-level system: An introduction to the special issue. Journal of Intervention and Statebuilding 6(3): 247-255. 
Kora S and Darboe M (2017) The Gambia's electoral earthquake. Journal of Democracy 28(2): 147-156.

Kreß C and Nussberger B (2017) Pro-democratic intervention in current international law: The case of The Gambia in January 2017. Journal on the Use of Force and International Law 4(2): 239-252.

Lanz D and Gasser R (2013) A Crowded Field: Competition and coordination in international peace mediation. Center for Mediation in Africa, Mediation Arguments No. 2. Pretoria: University of Pretoria.

Lederer E (2017) UN Adopts Resolution Backing Gambia's New President Barrow. APNews. Available at: https://apnews.com/44fe8d11a7134ad084794fb450c95556/un-adopts-resolution-backing-gambias -newpresident-barrow (accessed 20 August 2017).

Leininger J (2014) A Strong Norm for Democratic Governance in Africa. Discussion Paper. Stockholm: International Institute for Democracy and Electoral Assistance.

Maddy-Weitzman B (2012) The Arab League Comes Alive. Middle East Quarterly, Summer 2012: 71-78.

Nathan L (2013) A Clash of Norms and Strategies in Madagascar: Mediation and the AU Policy on unconstitutional change of government. Centre for Mediation in Africa, Mediation Arguments 4. Pretoria: University of Pretoria.

Nathan L (2016) Will the Lowest be First? Subsidiarity in Peacemaking in Africa. Conference Paper presented at the International Studies Association Annual Convention, Atlanta, March 16-19. Available at: https://www.up.ac.za/media/shared/237/PDFs/Publications/competition-and-subsidiarity-in-peacemaking-in-africa.zp84164.pdf

Obse K (2014) The Arab spring and the question of legality of democratic revolution in theory and practice: A perspective based on the African Union normative framework. Leiden Journal of International Law 27(4): 817-838.

Peerenboom R (2002) China's Long March Toward Rule of Law. Cambridge: Cambridge University Press.

Petersmann EU (2012) International Economic Law in the 21st Century: Constitutional pluralism and multilevel governance of interdependent public goods. Oxford: Hart Publishing.

Raz J (1977) The rule of law and its virtue. In: The Authority of Law. Oxford: Oxford University Press.

Rosenau J (2000) Change, complexity, and governance in a globalizing space. In: Pierre J (ed.) Debating Governance. Oxford: Oxford University Press, pp.167-200.

Rosenau J (2004) Strong demand, huge supply: Governance in an emerging epoch. In: Bache I and Flinders M (eds) Multi-Level Governance. Oxford: Oxford University Press, pp.31-48.

Scharpf F (2001) Notes toward a theory of multilevel governing in Europe. Scandinavian Political Studies 24(1): $1-26$.

Schmitter P and Kim S (2005) The experience of European integration and the potential for Northeast Asian integration. Available at: http://www.eastwestcenter.org/sites/default/files/private/PSwp010.pdf (accessed 20 November 2018).

Souaré I (2014) The African union as a norm entrepreneur on military coups d'État in Africa (1952-2012): An empirical assessment. The Journal of Modern African Studies 52(1): 69-94.

Southern African Development Community (2001) Protocol on Politics, Defence and Security Cooperation. Gaborone: Southern African Development Community.

Sukma R (2009) Democracy Building in South East Asia: The ASEAN Security Community and Options for the European Union. Discussion Paper. Stockholm: International Institute for Democracy and Electoral Assistance.

Tamanaha B (2004) On the Rule of Law: History, politics, theory. Cambridge: Cambridge University Press.

Tamanaha B (2008) Understanding legal pluralism: Past to present, local to global. Sydney Law Review 30: 374-411.

Tzanakopoulos A (2011) The UN/French use of force in Abidjan: Uncertainties regarding the scope of UN authorizations. Available at https://www.ejiltalk.org/the-un-use-of-force-in-abidjan/ (accessed 10 November 2018)

United Nations (2012) Guidance for Effective Mediation. New York: United Nations.

United Nations Security Council (2017a) Resolution 2337. New York: United Nations.

United Nations Security Council (2017b) Peace Consolidation in West Africa, S./PV.7866. New York: United Nations. 
Vandeginste S (2013) The African Union, constitutionalism and power sharing. Journal of African Law 57(2): $1-28$.

Waldron J (2008) The Concept and the Rule of Law. Working Paper No. 08-50, New York: NYU School of Law Public Law and Legal Theory.

What's in Blue (2017)Resolution on The Gambia. Available at: http://www.whatsinblue.org/2017/01/resolution -on-the-gambia.php (accessed 20 August 2017)

White N (2007) Hierarchy in organizations: Regional bodies and the United Nations. In: Tsagourias N (ed.) Transnational Constitutionalism: International and European Perspectives. Cambridge: Cambridge University Press, pp.135-159.

Wiebusch M (2016) The Role of Regional Organizations in the Protection of Constitutionalism. Discussion Paper. Stockholm: International Institute for Democracy and Electoral Assistance.

\section{Author biography}

Theresa Reinold is a junior professor of Global and Transnational Cooperation Research at Duisburg-Essen University. Trained as a Political Scientist, her research interests lie at the intersection of International Relations Theory and International Law. She is currently carrying out a two-year research project entitled 'The rule of law in African regionalism', funded by the Thyssen Foundation, which explores how global rule of law scripts are translated into (sub-) regional African practices. Her work has been published inter alia in The American Journal of International Law, The Review of International Studies, The International Journal of Constitutional Law and Global Constitutionalism. 


\section{DuEPublico}

Duisburg-Essen Publications online
UNIVERSITÄT

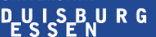

offen im Denken

Ub $\begin{aligned} & \text { universitäts } \\ & \text { bibliothek }\end{aligned}$

This text is made available via DuEPublico, the institutional repository of the University of Duisburg-Essen. This version may eventually differ from another version distributed by a commercial publisher.

\section{DOI: $\quad 10.1177 / 0021909618824348$}

URN: urn:nbn:de:hbz:464-20210504-165914-9

Reinold, T. (2019). Multi-level Approaches to Countering Unconstitutional Changes of Government in Africa: Implications for the Rule of Law. Journal of Asian and African Studies, 54(4), 467-484. https://doi.org/10.1177/0021909618824348

This publication is with permission of the rights owner freely accessible due to an Alliance licence and a national licence (funded by the DFG, German Research Foundation) respectively.

(C) The Author(s) 2019. All rights reserved. 